\title{
Phosphorus-limited bacterioplankton growth in the Sargasso Sea
}

\author{
James B. Cotner ${ }^{1, *}$, James W. Ammerman ${ }^{2}$, Emily R. Peele ${ }^{3}$, Ellen Bentzen ${ }^{4}$ \\ ${ }^{1}$ Department of Wildlife and Fisheries Sciences, Texas A\&M University, College Station, Texas 77843-2258, USA \\ ${ }^{2}$ Department of Oceanography, Texas A\&M University, College Station, Texas 77843, USA \\ ${ }^{3}$ Department of Biology, Western Washington University, Bellingham, Washington 98225, USA \\ ${ }^{4}$ Trent University, Department of Environmental and Resource Studies, Peterborough, Ontario, Canada K9J 7B8
}

\begin{abstract}
Oceanic central gyres cover large areas of the earth and contribute significantly to global productivity. Oceanic phytoplankton production is believed to be limited by nitrogen (N) in central gyres and iron ( $\mathrm{Fe}$ ) in high-nutrient low-chlorophyll regions. Bacterioplankton have been less studied but are believed to be limited by organic carbon. We report here that bacterioplankton in the Sargasso Sea were phosphorus (P) limited on cruises in 1992 and 1993. This assertion is supported by measurements of high dissolved and particulate N:P and C:P ratios, high alkaline phosphatase activity and phosphate uptake rates, and bacterioplankton growth rate responses in bioassays where inorganic $\mathrm{P}$ was added. Particulate C:P ratios were always higher than the Redfield ratio (106:1) and occasionally greater than 400:1. N:P ratios were 75:1 and 46:1 on 2 cruises and time-series data indicated that ratios were always greater than 24:1 over nearly a 2 yr span. Phosphate concentrations were extremely low in the euphotic zone $(<10 \mathrm{nM})$ and biomass-normalized alkaline phosphatase activities indicated moderate to severe P limitation, with most severe limitation occurring in the spring. Bioassays indicated that heterotrophic bacteria may be P limited in the northwestern Sargasso Sea, especially in the spring. Limitation by $\mathrm{P}$ and not dissolved organic carbon may explain why dissolved organic carbon accumulates in the water column at that time.
\end{abstract}

KEY WORDS: Bacterioplankton · Phosphorus · Biogeochemistry · Carbon · Phytoplankton

\section{INTRODUCTION}

Despite low nutrient availability in oceanic central gyres, these extensive areas contribute significantly to global productivity (Martin et al. 1987). Primary productivity in gyres impacts the global carbon cycle through atmospheric $\mathrm{CO}_{2}$ fixation and the subsequent flux of organic carbon to the deep ocean. Heterotrophic bacteria are a significant component of the microbial flora in these environments (Fuhrman et al. 1989, Li et al. 1992) and impact dissolved organic carbon (DOC) pools through their metabolic activities. Consequently, processes controlling planktonic productivity in these gyres have important impacts on global biogeochemical cycles.

\footnotetext{
•E-mail: j-cotner@tamu.edu
}

Any nutrient can limit productivity in aquatic environments when the availability of that nutrient is low relative to the biomass requirements of the organism (Redfield 1958). Organic carbon (C) is presumed to limit bacterioplankton growth in the open ocean (Kirchman 1990), but few studies have been performed on this topic. Phosphorus (P) limitation of bacterioplankton growth has recently been demonstrated in several marginal seas (Zweifel et al. 1993, Pomeroy et al. 1995). Bacterioplankton are an important constraint on $\mathrm{P}$ availability in freshwater environments (Currie \& Kalff 1984a, b, Vadstein et al. 1988, Tarapchak \& Moll 1990, Bentzen et al. 1992, Cotner \& Wetzel 1992). However, little work has been done to examine bacterial nutrient limitation in the Sargasso Sea, a large subtropical gyre in the North Atlantic. In this region of the ocean, dissolved inorganic N:P ratios are anomalously high in surface water (Fanning 1992), i.e. P concentra- 
tions are low relative to $\mathrm{N}$, and heterotrophic bacteria have been shown to have a high P requirement (Bratbak 1985, Vadstein et al. 1988); therefore, $P$ was believed to be important to growth of these organisms.

\section{MATERIALS AND METHODS}

Study area. We examined nutrient dynamics in the Sargasso Sea during 2 cruises in August 1992 and March 1993 at the U.S. Joint Global Ocean Flux Study (JGOFS) site near Bermuda $\left(31^{\circ} 50^{\prime} \mathrm{N}, 64^{\circ} 10^{\prime} \mathrm{W}\right.$ ). Plankton in Sargasso Sea surface waters, like other nutrient-depleted subtropical gyres, is dominated by prokaryotic biomass. Approximately $50 \%$ of the biomass is heterotrophic bacteria and nearly half of the autotrophic biomass is composed of Prochlorococcus and Synechococcus sp., small photosynthetic prokaryotes (Li et ai. 1992).

Bioassays. Nutrient limitation of heterotrophic bacteria was assessed by adding various nutrients to seawater and measuring the effects of these additions on bacterial growth and biomass. These experiments were conducted to determine what nutrient potentially limited the growth of heterotrophic bacteria in the Sargasso Sea. Samples for experiments were collected from $20 \mathrm{~m}$ depth because microbial activity is typically maximal near this region of the mixed layer. Bacterial thymidine and leucine incorporation rates were low but typically near maximal rates in the upper $50 \mathrm{~m}$ (Carlson et al. 1996). Annual primary productivity is highest near the surface and rates below $80 \mathrm{~m}$ are typically less than $1 \mathrm{mg} \mathrm{C} \mathrm{m} \mathrm{m}^{-3} \mathrm{~d}^{-1}$ (Michaels et al. 1994).

Whole seawater was enriched with $\mathrm{KH}_{2} \mathrm{PO}_{4}$ (100 nM $\mathrm{P}$ addition), $\mathrm{NH}_{4} \mathrm{Cl}$ [1500 (August) or 500 (March) nM $\mathrm{N}$ addition], or glucose [36 (August) or 6 (March) $\mu \mathrm{M}$ as C] before incubating at ambient temperature and in light conditions similar to those found at the depth of collection (August) or at ambient temperature and in the dark (March). Although ambient phosphate and ammonium concentrations were near detection limits (Michaels et al. 1994), we added phosphate to increase ambient phosphate concentrations by a factor of 10 to insure that sufficient quantities were available throughout the duration of the experiments. $N$ (as ammonium) and organic $C$ (as glucose) were added at Redfield ratios (relative to added $P$ ) in August, but in March, N:P and C:P ratios were adjusted down to compensate for the higher $P$ requirement of heterotrophic bacteria than phytoplankton (Vadstein et al. 1988, Vadstein \& Olsen 1989). In March, whole seawater was diluted $1: 1$ with $0.2 \mu \mathrm{m}$. pore-size filtered seawater to minimize the impact of grazers on bacterial biomass accumulation. Control treatments had no nu- trients added. Samples were removed for analyses $48 \mathrm{~h}$ after initiation of the incubation. Our measurements indicated maximal activity responses occurred between 24 and $48 \mathrm{~h}$ after experiments were initiated. Carlson \& Ducklow (1996) also observed maximum responses of bacteria to nutrient additions 40 to $50 \mathrm{~h}$ after initiation of similar Sargasso Sea experiments. Bacterial abundance was determined by the epifluorescence method of Hobbie et al. (1977). Thymidine incorporation rates were measured by the method of Wicks \& Robarts (1987).

Chemical and physiological measurements. Particulate $\mathrm{C}$ and $\mathrm{N}$ were measured with a Control Equipment Corporation (CEC) 240-XA Elemental Analyzer. Approximately $2 \mathrm{l}$ was filtered through pre-combusted $\left(400^{\circ} \mathrm{C}\right)$ glass fiber (GF/F) filters; filters were dried, combusted and analyzed. These data are provided from the Bermuda Atlantic time-series (BATS) measurements. Particulate $P$ was determined spectrophotometrically after filtration (4 l) onto filters (GF/F) and combustion of the material on the filters (Solorzano \& Sharp 1980). Particulate nutrient ratios were estimated by integrating particulate organic carbon, nitrogen and phosphorus concentrations over the upper $80 \mathrm{~m}$ of the water column.

An upper limit for phosphate concentrations $\left(\mathrm{PO}_{4}\right.$ $K_{t}+S_{n}$ ) was estimated kinetically from the half-saturation constant for $\mathrm{PO}_{4}$ uptake (Bentzen \& Taylor 1991). Conventional colorimetric analyses in the euphotic zone indicated average values near to or below the detection limit for phosphate in August and March. In August, colorimetric measurements at the BATS site indicated an average phosphate concentration of ca $10 \mathrm{nM}$ in the euphotic zone, and in March, all values in the euphotic zone were less than the detection limit. Phosphate uptake kinetic constants (half-saturation constant $\left(K_{t}+S_{n}\right)$ and $\left.V_{\max }\right]$ were determined by adding tracer levels of ${ }^{32} \mathrm{P}_{-} \mathrm{PO}_{4}$ with unlabeled phosphate at various concentrations and measuring isotope incorporation into particulate matter on $0.2 \mu \mathrm{m}$ poresize polycarbonate membrane filters (Cotner \& Wetzel 1992). Uptake at $V_{\max }$ was normalized to particulate $P$ concentrations (referred to as specific uptake) to estimate the turnover rate in biomass. Alkaline phosphatase activity (APA) was determined fluorometrically at saturating concentrations of the artificial substrate, methyl-umbelliferyl phosphate (Ammerman 1993). Incubations for uptake rate determinations and alkaline phosphatase assays were performed at ambient temperature.

Particulate nutrient concentrations were compared to the Redfield ratio (106 C:16 N:1 P; Redfield 1958) to infer the potential for nutrient limitation. This ratio represents the molar composition of biomass in most of the open ocean (Hecky et al. 1993). 


\section{RESULTS AND DISCUSSION}

\section{Bioassays}

Bioassay experiments conducted on both cruises demonstrated increased thymidine incorporation, a measure of heterotrophic bacterial growth rates, in treatments where P was added (Fig. 1). In August, all experimental treatments where $P$ was added had significantly higher thymidine incorporation rates than treatments without $\mathrm{P}(\mathrm{p}<0.05$; t-test). In March, both thymidine incorporation rates and bacterial abundances increased in $\mathrm{P}$-amended treatments $(\mathrm{p}<0.05)$. Furthermore, the percent increase in thymidine incorporation rates in $P$ treatments relative to controls was also higher in March than August (Fig. 1), suggesting greater potential for $\mathrm{P}$ limitation at that time.

Although bacterial growth rates increased with $\mathrm{P}$ additions on both cruises, bacterial abundance increased only in March, possibly because only the March experiments were pre-filtered and diluted to remove protozoan predators (Fig. 1). In similar experiments in the Sargasso Sea, bacterivorous predators were not abundant until approximately $100 \mathrm{~h}$ after initiation of the experiment and abundance only increased in $25 \%$ of the treatments (Carlson \& Ducklow 1996). However, their experimental design was similar to our March experiments, in that they were pre-filtered through a $0.8 \mu \mathrm{m}$ pore-size pre-filter and diluted with particle free water. Although we did not examine bioassay experiments for abundance of protists, they likely were more abundant in the August experiments because they were not pre-filtered and diluted.

If multiple nutrients limited the growth of bacterioplankton in these experiments, multiple additions of nutrients should have increased productivity or biomass more than single additions. Concomitant $N$ and $P$ additions in August and all possible combinations of $P$, $\mathrm{N}$ and glucose in March demonstrated similar biomass and growth responses as the single $\mathrm{P}$ addition treatment. These results suggest that $P$ was the primary nutrient limiting growth over the course of the March experiment.

Bioassay experiments performed in the 1960s, prior to current metal-clean techniques, suggested Felimited phytoplankton in this region (Menzel \& Ryther 1961). Recent experiments have also indicated potential for Fe limitation of heterotrophic bacteria in the Southern Ocean (Pakulski et al. 1996, Tortell et al. 1996). We did not examine the potential for bacterial Fe limitation in these experiments but more recent experiments using clean techniques did not suggest that bacterioplankton were Fe limited (J. B. Cotner, J. W. Ammerman \& R. Greene unpubl. results). Fe seems less likely to limit productivity in this region today than
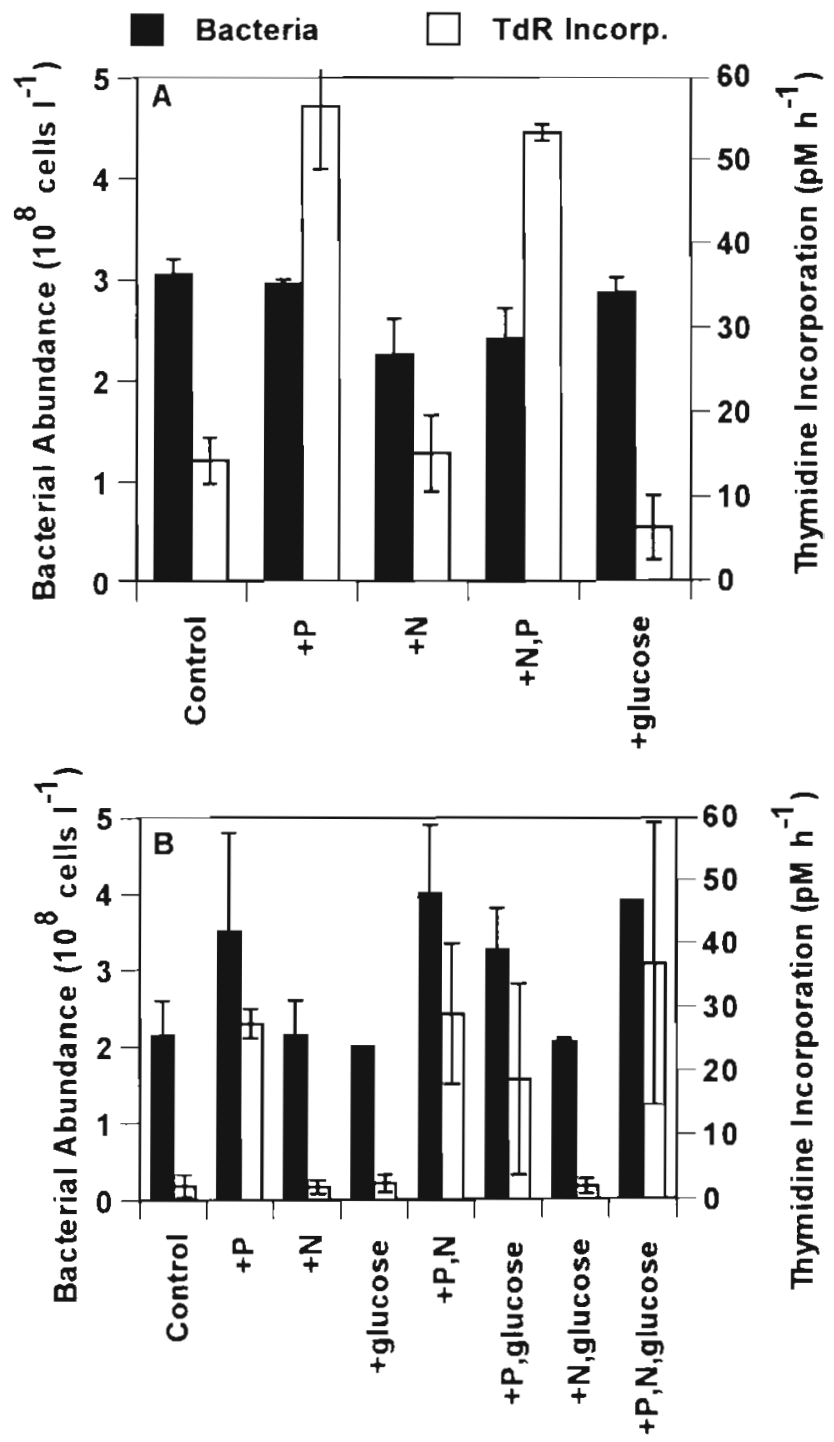

Fig. 1. Effects of phosphate (P), ammonium (N) and glucose on bacterial abundance and thymidine incorporation rate (TdR) in surface water collected at the Bermuda Atlantic time-series station in (A) August 1992 and (B) March 1993. Error bars represent 1 standard error of the mean. In August, $n=2$ to 4 , and in March $\mathrm{n}=2$, for each treatment

at the time these early experiments were performed because atmospheric dust concentrations have increased by a factor of 3 since the 1960s near Barbados and regions of the North Atlantic. Atmospheric Fe deposition rates are 1 to 2 orders of magnitude higher in the Atlantic than in the equatorial Pacific (Donaghay et al. 1991) and dissolved Fe:P ratios are 5 times higher in the Atlantic than the Pacific (Brand 1991). In addition to relieving the potential for Fe limitation in this region, increased Fe loading may decrease $P$ availability. Krom et al. (1991) speculated that Fe- and clay-rich particulates from the Sahara remove inorganic $P$ from the water column in the eastern Mediterranean Sea. 


\section{In situ measurements}

Physiological measurements also demonstrated potential for bacterial P limitation. Unlike bioassays, these measurements are indicative of nutrient sufficiency or deficiency of the total plankton, which includes both phytoplankton and bacterioplankton. Autotrophs and heterotrophs are similar in size in this region of the ocean so size-fractionation is not possible. Nonetheless, bioassays performed in the light did not suggest strong $P$ limitation of autotrophs (data not shown). For this reason, and also because heterotrophic bacteria constitute the largest pool of microbial biomass (Li et al. 1992, Caron et al. 1995), we used these bulk measurements to make inferences on the nutrient status of heterotrophic bacteria. P-specific phosphate uptake rates were high (Table $1 ; \mathrm{PO}_{4} \mathrm{POP}^{-1}$ )

Table 1. Kinetic phosphorus, particulate carbon and phosphorus and ratios (molar) measured at the Bermuda Atlantic timeseries station on cruises in August 1992 and March 1993. Values represent means ( $n=5$ to 7 ) of the upper part of the water column (less than $80 \mathrm{~m}$ ). Values in parentheses represent 1 standard error of the mean. In August, only 1 measurement was made for $\mathrm{PO}_{4} K_{t}+S_{n}$ and $\mathrm{PO}_{4} V_{\max }$, but these estimates are obtained from regressions of greater than 12 points and are robust, with standard error estimates less than $15 \%$ of the mean. Particulate organic carbon (POC), nitrogen (PON) and phosphorus ( $P O P$ ) values were integrated ( $n=3$ to 7 ) from the upper $80 \mathrm{~m}$ of the water column. Particulate nutrient ratios can be compared to the Redfield ratio (106:16:1) to infer potential nutrient limitation. APA:POC values from 0.24 to $1.2 \mathrm{nmol} \mathrm{P}(\mu \mathrm{mol} \mathrm{C})^{-1} \mathrm{~h}^{-1}$ suggest slight $\mathrm{P}$ limitation and values greater than 1.2 are indicative of severe $P$ limitation in freshwater (Healey \& Hendzel 1979)

\begin{tabular}{|c|c|c|}
\hline & August 1992 & March 1993 \\
\hline POP (nM) & $4(0.6)$ & $9(0.8)$ \\
\hline $\mathrm{PO}_{4} K_{t}+S_{n}(n M)$ & 10 & $5.4(0.5)$ \\
\hline $\mathrm{PO}_{4} V_{\max }\left(\mathrm{nM} \mathrm{h}^{-1}\right)$ & 0.78 & $0.82(0.11)$ \\
\hline $\mathrm{PO}_{4} \mathrm{POP}^{-1}\left(\mathrm{~h}^{-1}\right)$ & 0.20 & 0.09 \\
\hline APA $V_{\max }\left(\mathrm{nM} \mathrm{h}^{-1}\right)$ & $1.39(0.08)$ & $2.70(0.16)$ \\
\hline APA POP $-1\left(h^{-1}\right)$ & 0.35 & 0.30 \\
\hline APA:POC $\left[\mathrm{nmol} P(\mu \mathrm{mol} C)^{-1} \mathrm{~h}^{-1}\right]$ & 0.70 & 1.24 \\
\hline POC $\left.(\mathrm{mmol} \mathrm{m})^{-2}\right)$ & 170.9 & 181.2 \\
\hline PON (mmol m-2) & 27.0 & 32.6 \\
\hline POP (mmol m-2) & 0.36 & 0.71 \\
\hline$C: N$ & 6.33 & 5.57 \\
\hline C:P & 475 & 255 \\
\hline$N: P$ & 75 & 46 \\
\hline \multicolumn{3}{|c|}{$\begin{array}{l}\text { Abbreviations: } \\
\text { POP: particulate organic phosphorus; } \mathrm{PO}_{4} K_{\mathrm{i}}+S_{n} \text { : a kinetic } \\
\text { estimate of ambient phosphate concentrations plus the } \\
\text { half-saturation constant for } \mathrm{PO}_{4} \text { uptake; } V_{\text {max }} \text { : maximum } \\
\text { velocity for phosphate uptake } \mathrm{PO}_{4} \mathrm{POP}^{-1} \text { : phosphate up- } \\
\text { take at the maximum velocity normalized for POP concen- } \\
\text { trations; APA } V_{\max } \text { : alkaline phosphatase activity at the } \\
\text { maximum velocity; APA POP }{ }^{-1} \text { saturated alkaline phos- } \\
\text { phatase activity at } V_{\max } \text { normalized for POP concentrations }\end{array}$} \\
\hline
\end{tabular}

and ambient phosphate concentrations $\left(\mathrm{PO}_{4} K_{t}+S_{n}\right)$ were extremely low (5 to $10 \mathrm{nM}$ ) (Omarza-González \& Statham 1991) and varied little seasonally. These are among the lowest concentrations reported for any aquatic system (Cembella et al. 1984, Bentzen \& Taylor 1991; Table 1). Similar values for $K_{t}+S_{n}$ were reported for bacteria in Sandsfjord, Norway, and it was concluded that bacterioplankton were $\mathrm{P}$ limited there (Thingstad et al. 1993).

The phosphate uptake rates measured in our study were ca 3 to 100 times faster than previous measurements in the central North Pacific (Perry \& Eppley 1981), although previous rates were probably underestimated because glass-fiber filters were used instead of membrane filters. The phosphate turnover times (phosphate concentration divided by uptake rate) measured in the present study were ca $9 \mathrm{~h}$, which is 40 to 115 times faster than similar measurements in the centrai North Pacific (Perry \& Eppiey 1981).

One adaptation of organisms to nutrient depletion is an increase in the capacity for uptake of the limiting nutrient (Lean \& Pick 1981, Button 1985). To examine phosphate uptake capacity independent of biomass differences, we normalized uptake at $V_{\max }$ to the particulate $\mathrm{P}$ pool, often referred to as the specific uptake rate $\left(\mathrm{PO}_{4} \mathrm{POP}^{-1}\right.$; Table 1$)$. In a coastal $\mathrm{P}$-limited marine system, specific uptake rates varied from 0.01 to $0.30 \mathrm{~h}^{-1}$ (Thingstad et al. 1993), similar to values measured in the Sargasso Sea (Table 1). Highest specific uptake rates occurred in the most P-deficient region of the water column and heterotrophic bacterial fractions had higher specific uptake rates than phytoplankton fractions.

Because these rates are normalized for biomass, it enables comparisons with other systems of varying trophic state. These values are similar to measurements in P-limited freshwater systems. In P-limited Lake Erie, the specific uptake rate varied from 0.02 to $0.09 \mathrm{~h}^{-1}$ (Lean \& Pick 1981). In a P-limited Michigan (USA) kettle lake, $P$ turnover times in particulate matter were 0.06 to $0.5 \mathrm{~h}^{-1}$ (Cotner \& Wetzel 1992). These data suggest that $\mathrm{P}$ cycled through microbial biomass at very rapid rates which were comparable to rates measured in other P-limited systems.

The inverse of this rate represents the turnover time of $\mathrm{P}$ in biomass. These rates indicated that the turnover time of $\mathrm{P}$ in planktonic biomass was ca $5 \mathrm{~h}$ in August and $11 \mathrm{~h}$ in March. Although the phosphate uptake rate remained similar from August to March, the particulate $P$ pool doubled, giving lower values for $P$ normalized uptake.

APA is a useful physiological indicator of $\mathrm{P}$ limitation in oceanic systems because it is a de-repressible enzyme, produced only when internal $\mathrm{P}$ stores are depleted (Perry 1972). APA measurements on both 
cruises indicated high particulate phosphorus-normalized activity (Table 1). Few data exist for comparison in oceanic systems, but when rates were normalized to particulate carbon concentrations (Table 1), they were in a range of values that are indicative of moderate to severely P-limited freshwater plankton. APA normalized to particulate organic carbon values from 0.24 to 1.2 indicated moderate $P$ limitation and values greater than 1.2 suggested severe $P$ limitation (Healey \& Hendzel 1979). Although Healey \& Hendzel worked with freshwater plankton in their study, comparison of their threshold values to ours is consistent with the idea that some components of the plankton were $\mathrm{P}$ limited on both cruises.

Furthermore, APA rates in March were nearly double the rates measured in August, suggesting greater potential for $\mathrm{P}$ limitation at that time (Table 1). Higher rates in March are consistent with our bioassay results. In March, there was a greater increase in both bacterial biomass and in thymidine incorporation rates when $\mathrm{P}$ was added than in August. One explanation for severe $P$ limitation in spring is that water that is entrained into the mixed layer from deep-water regions during winter/spring mixing is low in P relative to $\mathrm{N}$. Consistent with this argument, Fanning (1992) found that this region of the ocean has high dissolved inorganic N:P ratios (50:1) occurring between the euphotic zone and $500 \mathrm{~m}$. When this low $\mathrm{P}$ water is mixed into the euphotic zone in the spring, it would likely force the organisms growing there into a P-deficient condition.

\section{Bacterial $P$ requirements}

Little is known about the nutrient demands of the dominant microbial autotrophs, Prochlorococcus and Synechococcus, that occur in this region. Both organisms are present year round with Synechococcus blooming during winter mixing and Prochlorococcus blooming after stratification develops in the spring (Olson et al. 1990). The high N:P ratios below the euphotic zone and high particulate $C: P$ ratios suggest that the autotrophs that are abundant in this region are tolerant of low P availability. In culture, an extremely high N:P ratio (150:1) was required to induce P limitation in Prochlorococcus (Parpais et al. 1995) and Synechococcus is a dominant phytoplankter in the Mediterranean Sea (Vaulot et al. 1996), another region of high dissolved N:P ratios. Both of these organisms are abundant in other regions of the ocean, however, where $\mathrm{N}$ or Fe are likely to be limiting. More work needs to be done to examine the nutrient requirements of these organisms and the nutrient regimes under which they are most abundant.
Heterotrophic bacteria have higher $\mathrm{P}$ requirements than most phytoplankton and therefore, may be more likely to be P-limited than primary producers. In an oligotrophic marine environment, Suttle et al. (1990) used a molar C:P ratio of $43: 1$ to model bacterial P dynamics. Bratbak (1985) reported C:P ratios of 7.7 and 56 for organic carbon-limited and P-limited mixed bacterial cultures, respectively. Data from freshwater environments also suggest low C:P ratios in heterotrophic bacteria. Vadstein et al. (1988) reported a median C:P ratio for natural bacteria of $29: 1$ and Jürgens \& Güde (1990) reported values from 40:1 to 80:1 in mixed culture. All of these values are less than Redfield (106:1) and, coupled with their high affinity for $P$ uptake at low phosphate concentrations (Cotner \& Wetzel 1992), suggests that heterotrophic bacteria may acquire a significant fraction of available $P$ in this oligotrophic environment. Assuming $20 \mathrm{fg}$ of carbon cell ${ }^{-1}$ (Lee \& Fuhrman 1987), a heterotrophic bacterial C:P ratio of 56:1 (P-limited bacteria; Bratbak 1985), and a mean bacterial abundance of $3 \times 10^{8}$ cells $1^{-1}$ ( $\mathrm{Li}$ et al. 1992), heterotrophic bacteria comprise ca $500 \mathrm{nM} \mathrm{C}$ and $8 \mathrm{nM}$ of the particulate $\mathrm{P}$ pool in the Sargasso Sea. Our measurements indicate that particulate $P$ concentrations were ca $10 \mathrm{nM}$ on average $(\mathrm{SE}=1 \mathrm{nM})$ and therefore $80 \%$ of this pool resides in heterotrophic bacteria. Similarly, Caron et al. (1995), using epifluorescence microscopy with carbon and nitrogen conversion factors, concluded that heterotrophic bacteria constituted the largest fraction of particulate carbon and nitrogen. Their estimates indicated heterotrophic bacteria constituted 10 to $20 \%$ of particulate carbon and 15 to $30 \%$ of particulate nitrogen.

Heterotrophic bacteria in the Sargasso Sea, however, are likely to have higher C:P ratios than reported in the literature. Our mean particulate C:P ratio in the upper water column from July 1991 to March 1993 was 260:1. If heterotrophic bacteria are $50 \%$ of the biomass and have a C:P ratio of ca 50:1, then the remainder of the planktonic biomass, primarily prokaryotic photoautotrophs, must have a C:P ratio of ca 450:1, which seems unrealistically high. Bratbak (1985) observed a $7 \times$ increase in C:P ratios of a mixed bacterial culture when nutrient limitation switched from organic carbon to $P$, and $C: P$ ratios of as high as $80: 1$ have been reported for freshwater bacterioplankton (Jürgens \& Güde 1990).

\section{Time-series measurements}

Time-series observations of organic nutrient pool sizes and ratios also supported the view that some portions of the plankton could be $\mathrm{P}$ limited (Table 1). Particulate C:P and N:P ratios (Table 1, Fig. 2) were 

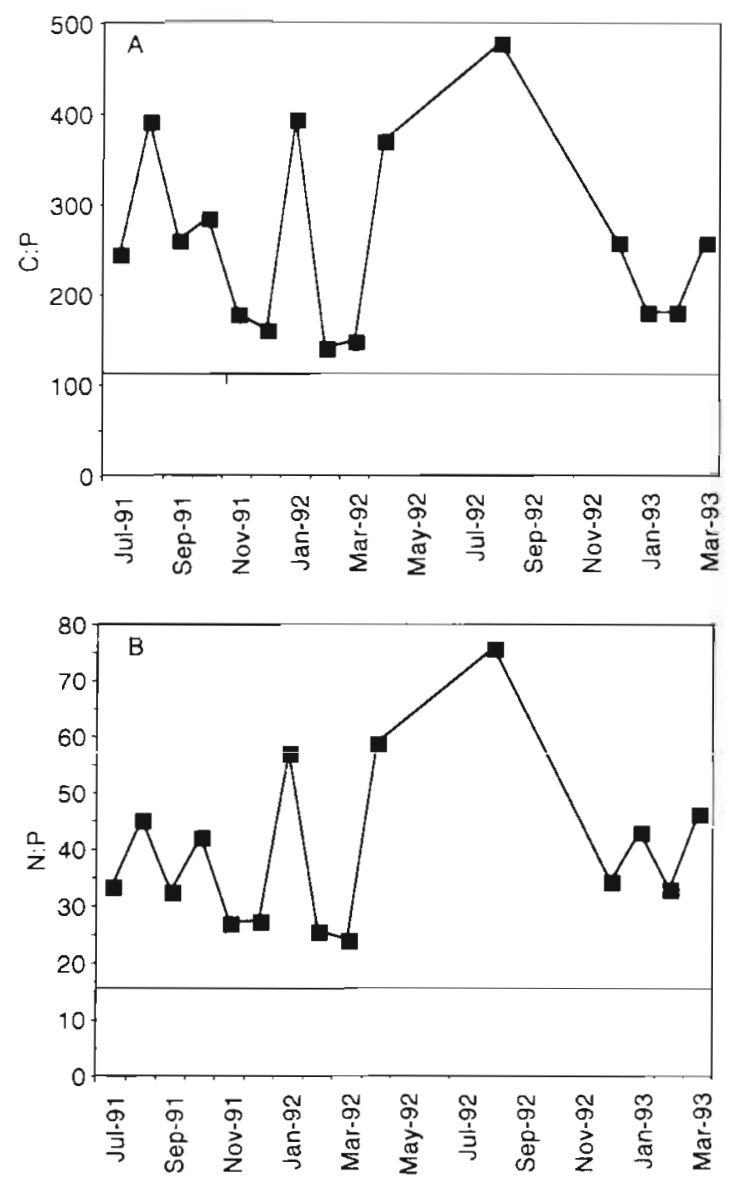

Fig. 2. Particulate (A) C:P and (B) N:P ratios (molar) from time series measurements at the Bermuda Atlantic time-series station. $C: P$ and $N: P$ ratios are plotted with the Redfield ratio (106:1 and 16:1, respectively) indicated by a horizontal line near the bottom of each figure. Values were derived by integrating the upper $80 \mathrm{~m}$ of the water column for POC, PON and $P O P$ and plotting their molar ratios. Mean standard errors for POC and PON were $\leq 10 \%$ of the mean and mean standard errors for POP were $\leq 20 \%$ of the mean

well above the Redfield ratio of 106:1 and 16:1, respectively, suggesting that $\mathrm{P}$ concentrations in biomass were low relative to both C and N. From July 1991 to March 1993, C:P ratios varied between 141:1 and 477:1 and N:P ratios varied between $24: 1$ and 75:1 (Fig. 2). The lowest C:P ratio observed in the present study was higher than that observed at the Hawaii JGOFS site when the phytoplankton were $P$ limited during the 1991-92 El Niño (Karl et al. 1995). The highest ratio we observed $(477: 1)$ was nearly 4 times the ratio observed by Karl et al. (1995). Similarly, our particulate N:P ratios were 25 to $400 \%$ higher than those observed in Hawaii during the P-limited El Niño event.

Significant quantities of detrital material collected on GF/F filters could have biased our inferred nutrient ratios for the plankton. However, Harris (1986) argued that detrital material in the open ocean has a similar stoichiometric composition as living cells because the turnover of both components is rapid. Even if this were not the case, high N:P and C:P ratios as a result of detrital material in our samples would support the argument that $\mathrm{P}$ was in greater demand, i.e. limiting to some portion of the planktonic community, because it was recycled more efficiently than other nutrients. The dissolved organic nutrient ratios (DOC:DOP and DON:DOP) were also high (ca 500:1 and 40:1, respectively - see below) and would not suggest that $P$ in particulate matter was merely leaching out into the dissolved phase and not consumed by plankton.

GF/F filters are known to allow bacteria-sized particles to pass through into the filtrate (Altabet 1990, Lee et al. 1995) and this could affect the particulate nutrient ratios reported here. In the Antarctic Ocean, about onethird of bacterial cells and 20 to $30 \%$ of bacterial biomass passed GF/F filters (Lee et al. 1995). In the Norih Atlantic, ca $30 \%$ of all particles passed GF/F filters (Altabet 1990). However, GF/F filters were as effective as membrane filters in the North Pacific at retaining chlorophyll (Chavez et al. 1995). Comparisons of POP concentrations measured with GF/F and $0.2 \mu \mathrm{m}$ poresize polycarbonate filters at the BATS site indicated that GF/F filters were $30 \%$ more effective at retaining particulate P than polycarbonate filters (Fig. 3).

Inefficient retention of heterotrophic and autotrophic picoplankton would cause an underestimation of the particulate matter concentrations in the present study. However, nutrient ratios should not be affected unless the particles passing the filter had significantly different nutrient stoichiometries than the retained particles. As discussed above, heterotrophic bacteria typically have lower C:P as well as C:N ratios relative to phytoplankton and therefore loss of bacterial biomass

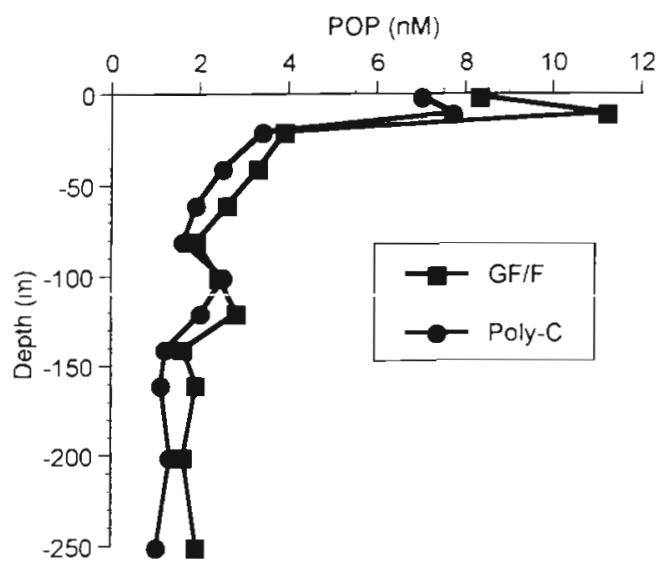

Fig. 3. Depth profile of POP concentrations determined using $\mathrm{GF} / \mathrm{F}$ and $0.2 \mu \mathrm{m}$ pore-size polycarbonate filters. Samples for this profile were collected during the August 1992 cruise 
through the filter could increase the ratios measured at the time-series station. The extent to which ratios are exaggerated depends on what fraction of the picoplankton is lost through the filter and the degree that ratios of lost material differ from retained material. In the Sargasso Sea, Altabet (1990) found 5\% deviation of the C:N ratio of particles that passed a GF/F filter relative to those collected on a $0.2 \mu \mathrm{m}$ pore-size filter.

Dissolved organic $N$ and $P$ data also suggest that $P$ is deficient in this region. Although dissolved organic $N$ was not measured on our cruises, other measurements in this region indicated values of ca $4.6 \mu \mathrm{M}$ (D. Hansell pers. comm.). Our measurements of dissolved organic P concentrations were $0.12(\mathrm{SE}= \pm 0.01)$ and $0.11(\mathrm{SE}=$ $\pm 0.00) \mu \mathrm{M}$ on the August and March cruises and, therefore, dissolved organic N:P ratios were ca 40:1, also above the Redfield ratio (16:1). DOC concentrations vary from ca 65 to $75 \mu \mathrm{M}$ at BATS (Carlson et al. 1994, Carlson \& Ducklow 1996), giving DOC:DOP ratios of over 500:1 on both cruises. These data suggest that $\mathrm{P}$ is efficiently regenerated from dissolved organic matter in the euphotic zone. Alkaline phosphatase enables plankton to remove inorganic $\mathrm{P}$ from dissolved organic matter and the high phosphatase activity we observed is consistent with the high DOC and DON to DOP ratios measured.

\section{Significance to carbon cycling}

P limitation in the ocean may be more common than previously thought. Components of both the phytoplankton (Berland et al. 1980) and bacterioplankton (Thingstad \& Rassoulzadegan 1995) in the Mediterranean were shown to be $P$ limited. $P$ limitation has been demonstrated recently in plankton growing in the Pacific (Karl et al. 1995) and in phytoplankton (Smith \& Hitchcock 1994) and bacterioplankton growing in the Gulf of Mexico (Pomeroy et al. 1995). Furthermore, the recent discovery that a major constituent of dissolved organic matter in the Pacific is porin $\mathrm{P}$ (Tanoue et al. 1995), a protein produced in $\mathrm{P}$ limited bacterial cultures, suggests bacterial $\mathrm{P}$ limitation may be fairly cosmopolitan in this ocean, as well.

Other bioassay experiments performed in the Sargasso Sea by Carlson \& Ducklow (1996) suggested that organic carbon was the primary limiting factor to bacterial production in this region of the ocean. Although the potential for $\mathrm{P}$ limitation was examined in only 1 experiment, the greatest increase in bacterial abundance, biomass, and productivity (as measured by thymidine and leucine incorporation) was observed with organic carbon additions, as glucose, dissolved amino acids or as algal lysate, which would include other nutrients as well. Although organic carbon con- centrations are in excess of inorganic $\mathrm{N}$ and $\mathrm{P}$ concentrations in the euphotic zone, they hypothesized that most of the carbon is refractory to bacterial metabolism. The combined results of their experiments and stimulation of bacterial productivity by $\mathrm{P}$ in the present experiments suggest that multiple nutrients may control bacterial productivity in this system. More of these experiments with greater temporal coverage need to be performed to resolve the importance of various inorganic and organic nutrients to bacterioplankton productivity.

The potential for $\mathrm{P}$ limitation may be highest in the spring when productivity, and presumably excretion of DOC, in the euphotic zone are highest (Michaels et al. 1994) and advection of high N:P water occurs (Fanning 1992). Consistent with these observations, spring bioassays and alkaline phosphatase activity indicated greatest potential P limitation at that time. DOC accumulates in the Sargasso Sea euphotic zone in the early spring and is exported to deep water during winter mixing (Carlson et al. 1994). Carlson et al. (1996) suggested that DOC accumulates during the spring bloom because the DOC produced is recalcitrant to degradation processes. Another possibility, suggested by our work, is that DOC may not decompose completely because heterotrophic bacteria are limited, not by DOC, but rather by inorganic $\mathrm{P}$ availability.

Acknowledgements. We thank the captains and crews of the RVs 'Herlopen' and 'Weatherbird', Anthony Michaels, Ann Close, Barry Bjork and others at the Bermuda Biological Station for providing assistance and data. Matt Ellis, Martha McRae, Rosa H. Sada and Jin-Seok Kim provided technical assistance. Farooq Azam, Leonard DiMichele, Rick Greene, George Jackson, Samantha Joye, Anthony Michaels, Gil Rowe, Daniel Vaulot and Kirk Winemiller and several anonymous reviewers provided comments on previous versions of this manuscript. This project was supported by a grant (OCE9019415) to J.W.A. from the US National Science Foundation.

\section{LITERATURE CITED}

Altabet M (1990) Organic C, N, and stable isotopic composition of particulate matter collected on glass-fiber and aluminum oxide filters. Limnol Oceanogr 35:902-909

Ammerman JW (1993) Microbial cycling of inorganic and organic phosphorus in the water column. In: Kemp PF, Sherr BF, Sherr EB, Cole JJ (eds) Handbook of methods in aquatic microbial ecology. Lewis, Boca Raton, p 649-660

Bentzen E, Taylor WD (1991) Estimating Michaelis-Menten parameters and lake water phosphate by the Rigler bioassay: importance of fitting technique, plankton size and substrate range. Can J Fish Aquat Sci 48:73-83

Bentzen E, Taylor WD, Millard ES (1992) The importance of dissolved organic phosphorus to phosphorus uptake by limnetic plankton. Limnol Oceanogr 37:217-231

Berland BR, Bonin DJ, Maestrini SY (1980) Azote ou phosphore? Considérations sur le 'paradoxe nutritionnel' de la mer méditerranée. Oceanol Acta 3:135-142

Brand LE (1991) Minimum iron requirements of marine phytoplankton and the implications for the biogeochemi- 
cal control of new production. Limnol Oceanogr 36 : $1756-1771$

Bratbak G (1985) Bacterial biovolume and biomass estimations. Appl Environ Microbiol 49:1488-1493

Button DK (1985) Kinetics of nutrient-limited transport and microbial growth. Microb Rev 49:270-297

Carlson CA, Ducklow HW (1996) Growth of bacterioplankton and consumption of dissolved organic carbon in the Sargasso Sea. Aquat Microb Ecol 10:69-85

Carlson CA, Ducklow HW, Michaels AF (1994) Annual flux of dissolved organic carbon from the euphotic zone in the northwestern Sargasso Sea. Nature 371:405-408

Carlson CA, Ducklow HW, Sleeter TD (1996) Stocks and dynamics of bacterioplankton in the northwestern Sargasso Sea. Deep Sea Res 43:491-515

Caron DA, Dam HG, Kremer P, Lessard EJ, Madin LP, Malone TC, Napp JM, Peele ER, Roman MR, Youngbluth MJ (1995) The contribution of microorganisms to particulate carbon and nitrogen in surface waters of the Sargasso Sea near Bermuda. Deep Sea Res 42:943-972

Cembella AD, Antia NJ, Harrison PJ (1984) The utilization of inorganic and organic phosphorus compounds as nutrients by eukaryotic microalgae: a muitidiscipinary perspective: Part 1. Crit Rev Microbiol 10:317-391

Chavez FP, Buck KR, Bidigare RR, Karl DM, Hebel D, Latasa M. Campbell L, Newton J (1995) On the chlorophyll a retention properties of glass-fiber $G F / F$ filters. Limnol Oceanogr 40:428-433

Cotner JB Jr, Wetzel RG (1992) Uptake of dissolved inorganic and organic phosphorus compounds by phytoplankton and bacterioplankton. Limnol Oceanogr 37:232-243

Currie DJ, Kalff $J$ (1984a) Can bacteria outcompete phytoplankton for phosphorus? A chemostat test. Microb Ecol 10:205-216

Currie DJ, Kalff J (1984b) A comparison of the abilities of freshwater algae and bacteria to acquire and retain phosphorus. Limnol Oceanogr 29:298-310

Donaghay PL, Liss PS, Duce RA, Kester DR, Hanson AK, Villareal T, Tindale NW, Gifford DJ (1991) The role of episodic atmospheric nutrient inputs in the chemical and biological dynamics of aceanic ecosystems. Oceanography $4: 62-70$

Fanning KA (1992) Nutrient provinces in the sea: concentration ratios, reaction rate ratios, and ideal covariation. J Geophys Res 97:5693-5712

Fuhrman JA, Sleeter TD, Carlson CA, Proctor LM (1989) Dominance of bacterial biomass in the Sargasso Sea and its ecological implications. Mar Ecol Prog Ser 57: $207-217$

Harris GP (1986) Phytoplankton ecology. Chapman and Hall, New York

Healey FP, Hendzel LL (1979) Fluorometric measurement of alkaline phosphatase activity in algae. Freshwat Biol 9: $429-439$

Hecky RE. Campbell P. Hendzel LL (1993) The stoichiometry of carbon, nitrogen, and phosphorus in particulate matter of lakes and oceans. Limnol Oceanogr 38:709-724

Hobbie JE, Daley RJ, Jasper S (1977) Use of Nuclepore filters for counting bacteria by fluorescence microscopy. Appl Environ Microbiol 33:1225-1228

Jürgens K, Güde H (1990) Incorporation and release of phosphorus by planktonic bacteria and phagotrophic flagellates. Mar Ecol Prog Ser 59:271-284

Karl DM, Leteller R, Hebel D, Tupas L, Dore J, Christian J, Winn C (1995) Ecosystem changes in the North Pacific subtropical gyse attributed to the 1991-92 El Niño. Nature $373: 230-234$
Kirchman D (1990) Limitation of bacterial growth by dissolved organic matter in the subarctic Pacific. Mar Ecol Prog Ser $62: 47-54$

Krom MD, Kress N, Brenner S, Gordon LI (1991) Phosphorus limitation of primary productivity in the eastern Mediterranean Sea. Limnol Oceanogr 36:424-432

Lean DRS, Pick FR (1981) Photosynthetic response of lake plankton to nutrient enrichment: a test for nutrient limitation. Limnol Oceanogr 26:1001-1019

Lee S, Fuhrman JA (1987) Relationships between biovolume and biomass of naturally derived marine bacterioplankton. Appl Environ Microbiol 53:1298-1303

Lee S, Kang YC, Fuhrman JA (1995) Imperfect retention of natural bacterioplankton cells by glass fiber filters. Mar Ecol Prog Ser 119:285-290

Li WKW, Dickie PM, Irwin BD, Wood AM (1992) Biomass of bacteria, cyanobacteria, prochlorophytes and photosynthetic eukaryotes in the Sargasso Sea. Deep Sea Res 39: $501-519$

Martin JH, Knauer GA, Karl DM, Broenkow WW (1987) VERTEX: carbon cycling in the northeast Pacific. Deep Sea Res 34:267-285

Mienzel DW, Ryther JH (1961) Nutrients limiting the production of phytoplankton in the Sargasso Sea, with special reference to iron. Deep Sea Res 7:276-281

Michaels AF, Knap AH, Dow RL, Gundersen K, Johnson RJ, Sorensen J, Close A, Knauer GA, Lohrenz SE, Asper VA, Tuel M, Bidigare R (1994) Seasonal patterns of ocean biogeochemistry at the United States JGOFS Bermuda Atlantic Time-Series study site. Deep Sea Res I (Oceanogr Res) 41:1013-1038

Olson RJ, Chisholm SW, Zettler ER, Altabet MA, Dusenberry JA (1990) Spatial and temporal distributions of prochlorophyte picoplankton in the North Atlantic Ocean. Deep Sea Res 37:1033-1051

Omarza-González FI, Statham PJ (1991) Determination of dissolved inorganic phosphorus in natural waters at nanomolar concentrations using a long capillary cell detector. Anal Chim Acta 244:63-70

Pakulski JD, Coffin RB, Kelley CA, Holder SL, Downer R, Aas P, Lyons MM, Jeffrey WH (1996) Iron stimulation of Antarctic bacteria. Nature 383:133-134

Parpais J, Marie D, Partensky F, Morin P, Vaulot D (1996) Effects of phosphorus starvation on the cell cycle of the photosynthetic prokaryote Prochlorococcus spp. Mar Ecol Prog Ser 132:265 -274

Perry MJ (1972) Alkaline phosphatase activity in subtropical central North Pacific waters using a sensitive fluorometric method. Mar Biol 15:113-119

Perry MJ, Eppley RW (1981) Phosphate uptake by phytoplankton in the central North Pacific ocean. Deep Sea Res 28:39-49

Pomeroy LR, Sheldon JE, Sheldon WM, Peters F (1995) Limits to growth and respiration of bacterioplankton in the Gulf of Mexico. Mar Ecol Prog Ser 117:259-268

Redfield AC (1958) The biological control of chemical factors in the environment. Am Sci 46:205-221

Smith SM, Hitchcock GL (1994) Nutrient enrichments and phytoplankton growth in the surface waters of the Louisiana Bight. Estuaries 17:740-753

Solorzano L, Sharp JH (1980) Determination of total dissolved phosphorus and particulate phosphorus in natural waters. Limnol Oceanogr 25:754-758

Suttle CA, Fuhrman JA, Capone DG (1990) Rapid ammonium cycling and concentration-dependent partitioning of ammonium and phosphate: implications for carbon transfer in planktonic communities. Linnol Oceanogr 35:424-432 
Tanoue E, Nishiyama S, Kamo M, Tsugita A (1995) Bacterial membranes: possible source of a major dissolved protein in seawater. Geochim Cosmochim Acta 59:2643-2648

Tarapchak SJ, Moll R (1990) Phosphorus sources for phytoplankton and bacteria in Lake Michigan. J Plankton Res 12:743-758

Thingstad TF, Rassoulzadegan F (1995) Nutrient limitations, microbial food webs, and 'biological C-pumps' suggested interactions in a P-limited Mediterranean. Mar Ecol Prog Ser 117:299-306

Thingstad TF, Skjoldal EF, Bohne RA (1993) Phosphorus cycling and algal-bacterial competition in Sandsfjord, western Norway. Mar Ecol Prog Ser 99:239-259

Tortell PD, Maldonado MT, Price NM (1996) The role of heterotrophic bacteria in iron-limited ocean ecosystems. Nature 383:330-332

Responsible Subject Editor: Frede Thingstad, Roskilde, Denmark
Vadstein O, Jensen A, Olsen Y, Reinertsen H (1988) Growth and phosphorus status of limnetic phytoplankton and bacteria. Limnol Oceanogr 33:489-503

Vadstein O, Olsen Y (1989) Chemical composition and phosphate uptake kinetics of limnetic bacterial communities cultured in chemostats under phosphorus limitation. Limnol Oceanogr 34:939-946

Vaulot D, LeBot N, Marie D, Fukai E (1996) Effect of phosphorus on Synechococcus cell cycle in surface Mediterranean waters during summer. Appl Environ Microbiol 62:2527-2533

Wicks RJ, Robarts RD (1987) The extraction and purification of DN.A labeled with [methy] ${ }^{3} \mathrm{H}$ ] thymidine in aquatic bacterial production studies. J Plankton Res 9:1159-1166

Zweifel UL, Norrman B, Hagström $\AA$ (1993) Consumption of dissolved organic carbon by marine bacteria and demand for inorganic nutrients. Mar Ecol Prog Ser 101:23-32

Manuscript received: December 30, 1996

Revised version accepted: May 20, 1997 